Dział: Zootechnika

Copyright @Wydawnictwo Uniwersytetu Przyrodniczego w Poznaniu

\title{
LIGHT AND SCANNING ELECTRON MICROSCOPIC STUDY OF THE FILIFORM PAPILLAE OF THE TONGUE IN ADULT RABBIT (ORYCTOLAGUS CUNICULUS F. DOMESTICA, LINNAEUS 1758)
}

\author{
BADANIA BRODAWEK NITKOWATYCH JĘZYKA DOROSŁEGO KRÓLIKA \\ (ORYCTOLAGUS CUNICULUS F. DOMESTICA, LINNAEUS 1758) \\ W MIKROSKOPIE ŚWIETLNYM I ELEKTRONOWYM SKANINGOWYM
}

\begin{abstract}
Summary. This study was conducted on 10 tongues of adult rabbits (Oryctolagus cuniculus f. domestica), of both sexes (five females and five males). The filiform papillae of the tongue were studied, using light and scanning electron microscope. The filiform papillae were arranged on the dorsal surface of the apex and body of the tongue and on its margins. The investigation showed that there were single and complex filiform papillae on the rabbit tongue. These single filiform papillae were cone-shaped, similarly as their connective tissue cores. Complex papillae were palm-shaped and cone-shaped with three to seven processes. However, the number of processes towards the throat diminished. Connective tissue cores of these papillae had also processes. The filiform papillae consisted of an anterior and posterior epithelial cell column. The anterior epithelial cell column showed signs of parakeratinization or soft keratinization whereas the posterior epithelial cell column - hard keratinization. Between filiform papillae there was interpapillary epithelium which did not have any signs of keratinization.
\end{abstract}

Key words: rabbit, tongue, filiform papillae

\section{Introduction}

The general structure of a rabbit tongue was published in Barone's atlas (1973). Later, articles gave some more details about the structure of tongue papillae in adult rabbits.

\footnotetext{
*Financial support by State Committee for Scientific Research, grant No. 5 P06 D 01719.
} 
Kulawik, M., Godynicki, Sz., Frąckowiak, H. (2015). Light and scanning electron microscopic study of the filiform papillae of the tongue in adult rabbit (Oryctolagus cuniculus f. domestica, Linnaeus 1758). Nauka Przyr. Technol., 9, 1, \#12. DOI: 10.17306/J.NPT.2015.1.12

Kulawik and Godynicki (2006, 2007a, 2007b) described the foliate, fungiform and vallate papillae of the tongue of the rabbit. Fujimoto et al. (1993) investigated the morphogenesis of foliate papillae in prenatal and postnatal life. However, Kobayashi (1992) described morphology and connective tissue core of foliate papillae in adult rabbits. In the scientific literature the angioarchitecture of fungiform papillae of the rabbit was reported by Ojima et al. (1997). There is lack of results, which describe the filiform papillae on the rabbit tongue in detail. For this reason, we aimed to examine this papillae by light and scanning electron microscopes.

There is a very interesting correlation between the way animals feed, their diet and the habitat they live in, as well as their habits and their tongue anatomy and structure of their papillae (Okada and Schraufnagel, 2005; Yoshimura et al., 2008). Tongue papillae of vertebrates vary between species (Iwasaki, 2002). Some studies revealed that the filiform papillae of various species had a diverse structural organisation (Estecondo et al., 2001; Kullaa-Mikkonen et al., 1987). Furthermore, the shape of these papillae varies in different regions of the tongue (Kurtul and Atalgin, 2008). Therefore, in the present study the distribution and morphology of the filiform papillae of adult rabbit were investigated. The structure of the filiform papillae in the rabbit was compared with papillae of other animal species. Data acquired from examining the surface structures of the tongue of different species of animals are important, because they can be used in taxonomy (Emura et al., 2001, 2006; Iwasaki, 2002). This is essential if we are to learn more about the structure of connective tissue core of the tongue papillae. The surface of connective tissue core is somehow adjusted in its shape to the covering epithelium. A direct contact of these two tissues plays a crucial role in the process of morphogenesis. The interaction of epithelium and connective tissue is well known and mentioned in scientific articles by researchers (Mackenzie, 1984; Sanders, 1988).

\section{Materials and methods}

A total of 10 adult rabbits (five females and five males) of Californian breed, Oryctolagus cuniculus f. domestica, of both sexes were used in this study. The rabbits were six months old. Their tongues were collected immediately after slaughter from the local abattoir. Studies on animals were conducted with approval from the Local Ethics Committee, permission No. 4/2000.

For light microscopy, six tongues were fixed in $10 \%$ buffered formalin for $24 \mathrm{~h}$. The samples of filiform papillae from the apex and body of the tongue were chosen. The samples were dehydrated in ethanol, embedded with Paraplast ${ }^{\circledR}$ and cut into $3-5-\mu \mathrm{m}$ thick sections. The samples were cut in three planes, i.e. in the sagittal, transverse and horizontal planes. The Masson-Goldner and HE staining were applied in this study. The specimens were studied under a light microscope Jenaval (Carl Zeiss Jena).

For scanning electron microscopy, samples were taken from the same areas of the tongue to research under the light microscope. The samples of tissues were fixed in the Karnovsky solution $\left(4^{\circ} \mathrm{C}, \mathrm{pH} 7.2\right)$ for $24 \mathrm{~h}$. For the purpose of observations of the connective tissue core of filiform papillae, some samples after being fixed in the Karnovsky solution, were treated in $10 \% \mathrm{NaOH}$ solution for 14 days at room temperature. Then the 
Kulawik, M., Godynicki, Sz., Frąckowiak, H. (2015). Light and scanning electron microscopic study of the filiform papillae of the tongue in adult rabbit (Oryctolagus cuniculus f. domestica, Linnaeus 1758). Nauka Przyr. Technol., 9, 1, \#12. DOI: 10.17306/J.NPT.2015.1.12

samples were dehydrated in a graded ethanol series, critical point dried, mounted on aluminum stubs and coated with gold. The samples were observed at various angles under a scanning electron microscope Hitachi S-4200 and LEO 435VP.

\section{Results}

The filiform papillae were distributed on the entire dorsal surface of the apex and body of the tongue and on its margins. They were the most numerous papillae on the rabbit tongue. Only on the root of the tongue there were no filiform papillae. The papillae were tightly arranged. Tips of the filiform papillae were directed towards the throat.

Scanning electron microscope revealed, that the filiform papillae differed in shapes and structure depending on their distribution on the rabbit tongue. The research showed that on the rabbit tongue there were single and complex filiform papillae. Papillae which were distributed on the apex of the tongue and on its margins resembled single cones. Their tips were rounded or sharp (Fig. 1). Filiform papillae of cone-shaped were also present on the body of the tongue in front of intermolar eminence and on its sides. On the surface of papillae were numerous exfoliating epithelium cells. After removing the epithelium, the connective tissue cores of filiform papillae there were seen as single, conical protrusions. They were wider at the base and narrower on the tips (Fig. 2).

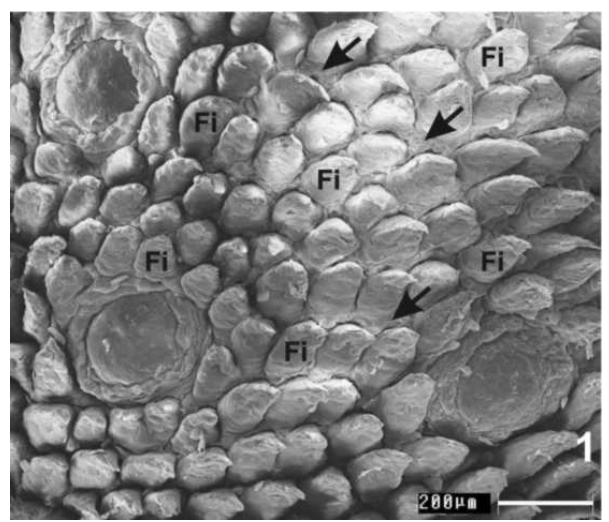

Fig. 1. Apex of the tongue of the rabbit: $\mathrm{Fi}-$ single cone-shaped filiform papillae, arrows interpapillary epithelium; scanning electron microscope, scale bar $=200 \mu \mathrm{m}$

Rys. 1. Wierzchołek języka królika: Fi - pojedyncze brodawki nitkowate o kształcie stożkowatym, strzałki - nabłonek międzybrodawkowy; mikroskop elektronowy skaningowy, skala $=200 \mu \mathrm{m}$

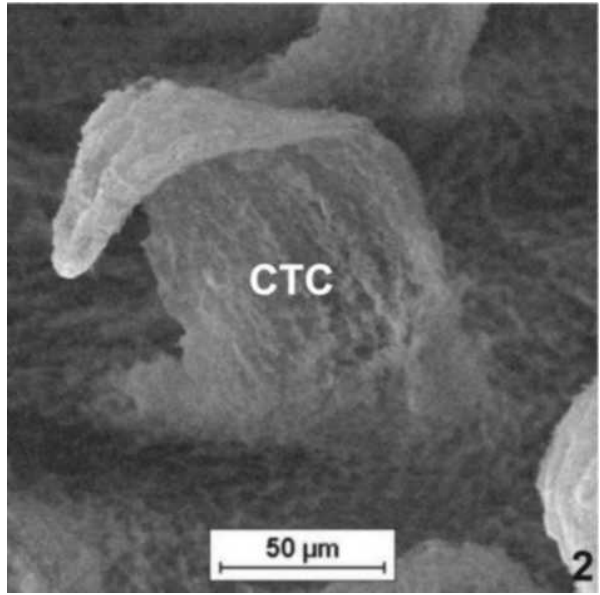

Fig. 2. CTC - connective tissue core of the single cone-shaped filiform papilla; scanning electron microscope, scale bar $=50 \mu \mathrm{m}$ Rys. 2. CTC - zrąb łącznotkankowy pojedynczej brodawki nitkowatej o kształcie stożkowatym; mikroskop elektronowy skaningowy, skala $=50 \mu \mathrm{m}$ 
Kulawik, M., Godynicki, Sz., Frąckowiak, H. (2015). Light and scanning electron microscopic study of the filiform papillae of the tongue in adult rabbit (Oryctolagus cuniculus f. domestica, Linnaeus 1758). Nauka Przyr. Technol., 9, 1, \#12. DOI: 10.17306/J.NPT.2015.1.12

In light microscopic investigation each filiform papilla had an anterior convex and posterior concave surface. The filiform papillae consisted of an anterior and posterior epithelial cells column. The epithelium of the anterior surface of the papillae, in the superficial layer contained remnants of nuclei. Keratohyaline granules were observed in the granular layer. These observations suggest that this is parakeratinization. In the epithelium of the posterior surface of the papillae, the superficial cells of stratum corneum were devoid of nuclear remnants. This area was strongly stained. The posterior cell column of the papillae did not contain keratohyalin granules. These are characteristic features of hard keratinization. The interpapillary epithelium was located in the area among the filiform papillae. It was nonkeratinized stratified squamous epithelium (Figs. 3, 4).

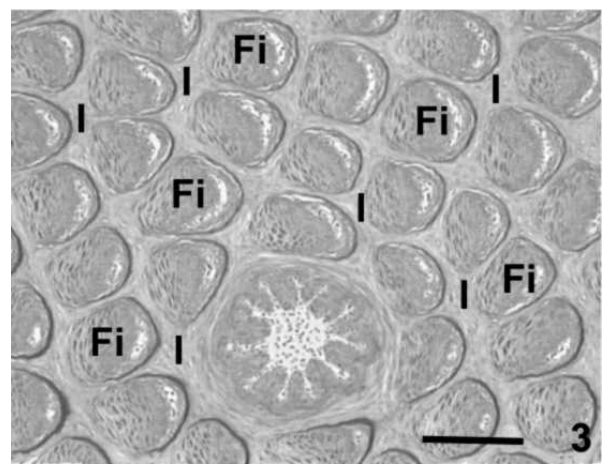

Fig. 3. Horizontal section of the single cone-shaped filiform papillae - Fi, I - interpapillary epithelium; light microscope, scale bar $=$ $100 \mu \mathrm{m}$

Rys. 3. Przekrój horyzontalny pojedynczych brodawek nitkowatych o kształcie stożkowatym - Fi, I - nabłonek międzybrodawkowy; mikroskop świetlny, skala $=100 \mu \mathrm{m}$

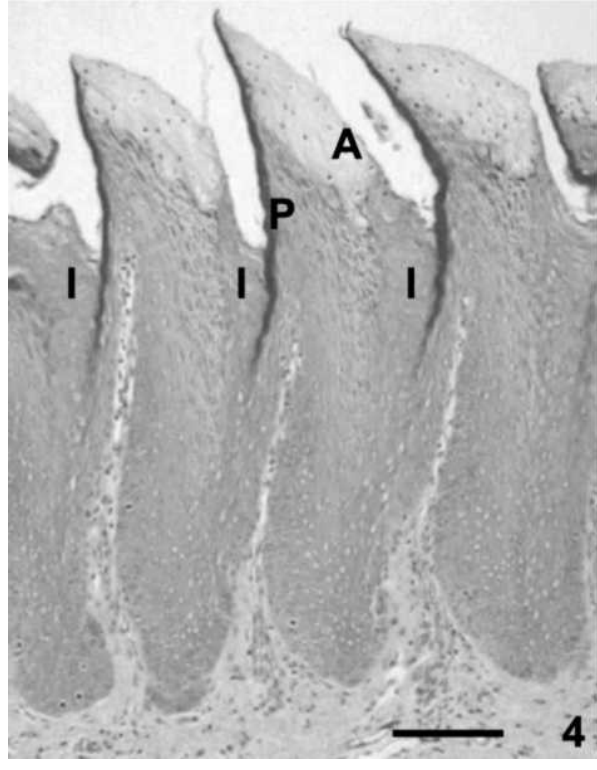

Fig. 4. Sagittal section of the single cone-shaped filiform papillae, I - interpapillary epithelium, A - anterior epithelial cell column, P - posterior epithelial cell column; light microscope, scale bar $=100 \mu \mathrm{m}$

Rys. 4. Przekrój strzałkowy pojedynczych brodawek nitkowatych o kształcie stożkowatym, I - nabłonek międzybrodawkowy, A przednia kolumna komórek nabłonkowych, P - tylna kolumna komórek nabłonkowych; mikroskop świetlny, skala $=100 \mu \mathrm{m}$

Scanning electron microscope showed, that on the intermolar eminence, the structure of filiform papillae was more complicated. The filiform papillae comprised of cent- 
Kulawik, M., Godynicki, Sz., Frąckowiak, H. (2015). Light and scanning electron microscopic study of the filiform papillae of the tongue in adult rabbit (Oryctolagus cuniculus f. domestica, Linnaeus 1758). Nauka Przyr. Technol., 9, 1, \#12. DOI: 10.17306/J.NPT.2015.1.12

ral papillary body from which some processes emerge. The papillae distributed on the anterior part of the intermolar eminence were palm-shaped. There were six-seven processes in each papilla. Processes were isolated. The connective tissue cores of these papillae were also palm-shaped (Figs. 5, 6).

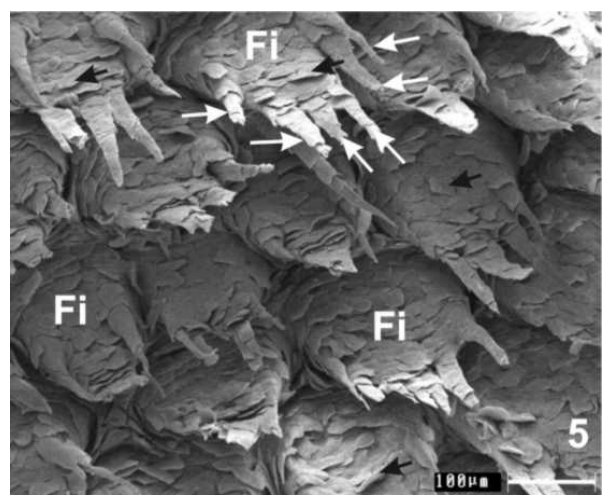

Fig. 5. Anterior region of the intermolar eminence: $\mathrm{Fi}$ - complex palm-shaped filiform papillae, white arrows indicate their projections, black arrows - desquamating epithelial cells; scanning electron microscope, scale bar $=100 \mu \mathrm{m}$

Rys. 5. Przedni obszar wału języka: Fi - złożone brodawki nitkowate o kształcie dłoniastym, białe strzałki wskazują ich wyrostki, czarne strzałki - złuszczające się komórki nabłonkowe; mikroskop elektronowy skaningowy, skala $=100 \mu \mathrm{m}$

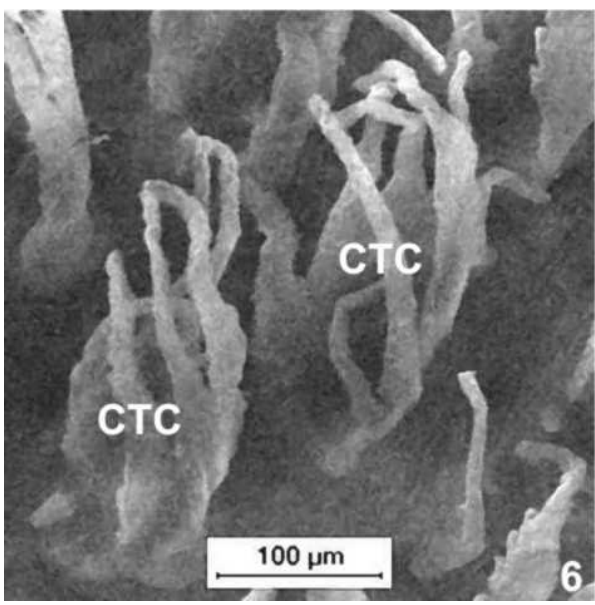

Fig. 6. CTC - connective tissue cores of the complex palm-shaped filiform papillae; scanning electron microscope, scale bar $=100 \mu \mathrm{m}$

Rys. 6. CTC - zręby łącznotkankowe złożonych brodawek nitkowatych o kształcie dłoniastym; mikroskop elektronowy skaningowy, skala $=100 \mu \mathrm{m}$

Towards caudal part of the tongue, on the itermolar eminence there were cone-shaped filiform papillae, which long processes of about five-six in number were distributed convergent. The process which was located on the very back on the papilla was the biggest one. The connective tissue cores of these papillae had very prominent projections (Figs. 7, 8). In the posterior part of the intermolar eminence the number of processes was reduced. Observations revealed, that the processes were rare and very small or absent in this part of the tongue (Fig. 9). The connective tissue cores of filiform papillae arranged by the root of the tongue were cone-shaped. They were similar to those described on the apex of the tongue.

Light microscopic observations revealed, that the epithelium of the anterior surface of the filiform papillae showed signs of soft keratinization. In the superficial layer there were no remnants of nuclei. Keratohyaline granules were observed in the granular layer. 
Kulawik, M., Godynicki, Sz., Frąckowiak, H. (2015). Light and scanning electron microscopic study of the filiform papillae of the tongue in adult rabbit (Oryctolagus cuniculus f. domestica, Linnaeus 1758). Nauka Przyr. Technol., 9, 1, \#12. DOI: 10.17306/J.NPT.2015.1.12

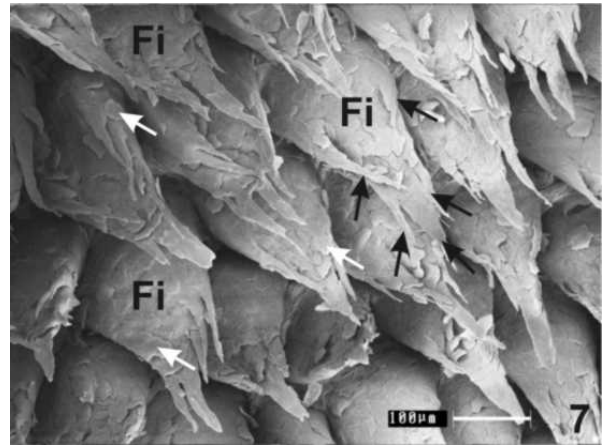

Fig. 7. Middle region of the intermolar eminence: $\mathrm{Fi}$ - complex cone-shaped filiform papillae, black arrows - projections, white arrows indicate desquamating epithelial cells; scanning electron microscope, scale bar = $100 \mu \mathrm{m}$

Rys. 7. Środkowy obszar wału języka: Fi złożone brodawki nitkowate o kształcie stożkowatym, czarne strzałki - wyrostki, białe strzałki wskazują złuszczające się komórki nabłonkowe; mikroskop elektronowy skaningowy, skala $=100 \mu \mathrm{m}$

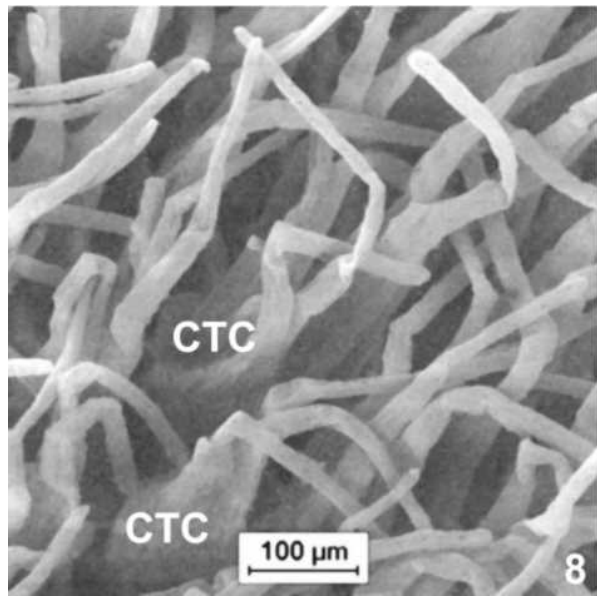

Fig. 8. CTC - connective tissue cores of the complex cone-shaped filiform papillae with long projections; scanning electron microscope, scale bar $=100 \mu \mathrm{m}$

Rys. 8. CTC - zręby łącznotkankowe złożonych brodawek nitkowatych o kształcie stożkowatym z długimi wyrostkami; mikroskop elektronowy skaningowy, skala $=100 \mu \mathrm{m}$

The epithelium of posterior side of papillae showed signs of hard keratinization. This epithelium shows distinctive layer of stratum corneum and lack of nuclei on this area. Keratohyaline granules were not observed. All processes of filiform papillae were covered with a well-visible stratum corneum (Figs. 10, 11).

\section{Discussion}

Filiform papillae are the only mechanical papillae, which are present on the rabbit tongue. They are present in great number similarly to other mammals, whose tongues have been examined (Choudhury et al., 2013; El-Bakry, 2010; Erdunchaolu et al., 2001; Kilinc et al., 2010; Kumar and Bate, 2004; Mohammed et al., 2014). These papillae play a big role in processing and grinding food in oral cavity. Such a large number of filiform papillae, as well as a type of epithelium keratinization, is undoubtedly connected with the sort of food, the way an animal feeds on it, the habitat which animals live in and their life-styles specific to their species. A tongue itself as the tool to clean fur and 
Kulawik, M., Godynicki, Sz., Frąckowiak, H. (2015). Light and scanning electron microscopic study of the filiform papillae of the tongue in adult rabbit (Oryctolagus cuniculus f. domestica, Linnaeus 1758). Nauka Przyr. Technol., 9, 1, \#12. DOI: 10.17306/J.NPT.2015.1.12

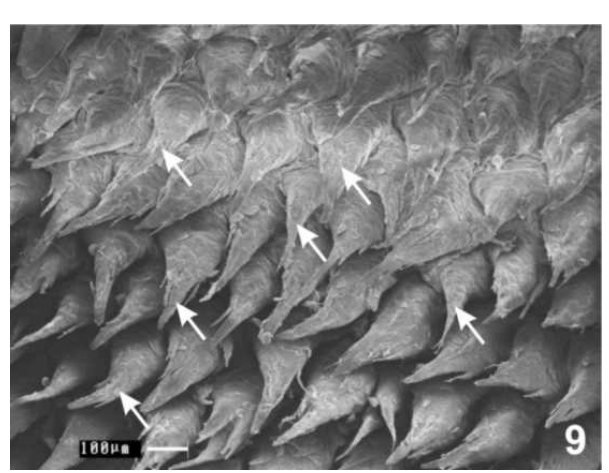

Fig. 9. Posterior region of the intermolar eminence: arrows indicate the filiform papillae; scanning electron microscope, scale bar = $100 \mu \mathrm{m}$

Rys. 9. Tylny obszar wału języka: strzałki wskazują brodawki nitkowate; mikroskop elektronowy skaningowy, skala $=100 \mu \mathrm{m}$

Fig. 11. Transverse section of the complex filiform papillae: arrows indicate the projections of papillae; light microscope, scale bar $=$ $100 \mu \mathrm{m}$

Rys. 11. Przekrój poprzeczny złożonych brodawek nitkowatych: strzałki wskazują wyrostki brodawek, mikroskop świetlny, skala = $100 \mu \mathrm{m}$

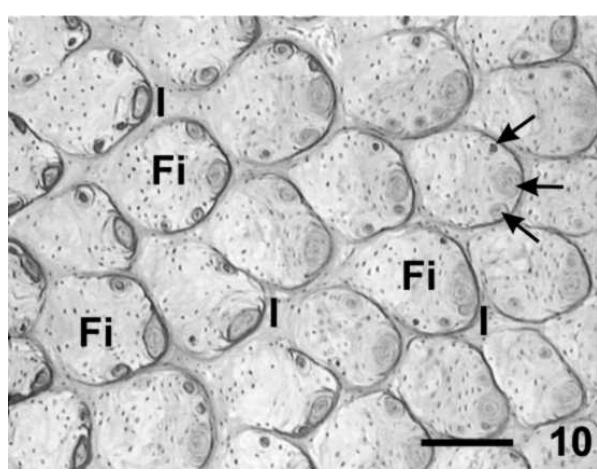

Fig. 10. Horizontal section of the complex filiform papillae $-\mathrm{Fi}$, arrows indicate their projections, I - interpapillary epithelium; light microscope, scale bar $=100 \mu \mathrm{m}$

Rys. 10. Przekrój horyzontalny złożonych brodawek nitkowatych - Fi, strzałki wskazują ich wyrostki, I - nabłonek międzybrodawkowy; mikroskop świetlny, skala $=100 \mu \mathrm{m}$

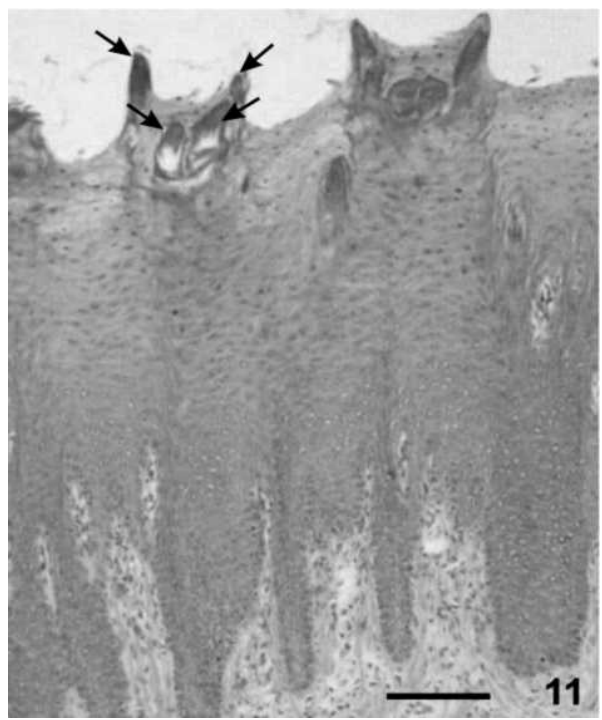

skin in the process of evolution probably influenced the shape of tongue mucous membrane and structural diversity of filiform papillae. That is why there are so many morphological types of filiform papillae on the tongue in one species of animals. Various forms of these papillae are connected with diversity of tasks to be accomplished by tongue, which was mentioned by (Iwasaki, 2002). 
Kulawik, M., Godynicki, Sz., Frąckowiak, H. (2015). Light and scanning electron microscopic study of the filiform papillae of the tongue in adult rabbit (Oryctolagus cuniculus f. domestica, Linnaeus 1758). Nauka Przyr. Technol., 9, 1, \#12. DOI: 10.17306/J.NPT.2015.1.12

There are filiform papillae of different shapes on the rabbit tongue. They differ according to their distribution on the tongue. The hairy armadillo (Estecondo et al., 2001), reeves' muntjac deer (Zheng and Kobayashi, 2006), Saanen goat (Kurtul and Atalgin, 2008), albino rat (El-Bakry, 2010) and other species of animals also have several types of filiform papillae. For comparison, in Japanese monkey (Iwasaki et al., 1992) and Bactrian camel (Erdunchaolu et al., 2001) the structure of these papillae are generally identical in all areas of the tongue. Iwasaki et al. (1988) also noticed it in squirrel monkey and Burity et al. (2009) in golden-headed lion tamarin.

Study by scanning electron microscope revealed, that the processes of filiform papillae in the posterior part of the intermolar eminence were rare or absent. Emura et al. (2008) described, that in cape hyrax the number of processes was reduced, too. Different morphological types of filiform papillae, which have been described in this article, in rabbit and in other species, had the endings directed towards the root of the tongue. Additional processes which were found on the complex filiform papillae in rabbit were bent also towards the throat. Such structure of filiform papillae enables food to be transported towards throat and thus prevent it falling out from oral cavity. Filiform papillae with additional processes are present on the tongue of different animal species. These papillae are different in shape (Burity et al., 2009; Emura et al., 2006, 2008; Estecondo et al., 2001; Pastor et al., 2008). Scientific literature also informs that some morphological forms of filiform papillae occurring in different animal species are alike. For example filiform papillae which were arranged on the posterior part of intermolar eminence in rabbit and their connective tissue core were shaped palm likewise in papillae in treeshrew, described by Kobayashi and Wanichanon (1992). A similar morphological kind of filiform papillae was found and examined by Burity et al. (2009). Moreover, it is necessary to mention that single not branched filiform papillae are also common on the tongue of different species (Ciuccio et al., 2008; Estecondo et al., 2001).

The research conducted has shown that there are different types of the filiform papillae on the rabbit tongue. Similar observations were made by Silva et al. (2002). However, researchers showed that filiform papillae which were located in front of the intermolar eminence had different shapes than these in our study. Similar changes were noticed in the posterior part of the body of the tongue. These data can only suggest that different breeds of rabbits mean different shapes of filiform papillae on some areas of the tongue. Such divergences in one species demand carrying out further detailed research on other breeds of rabbit.

On the rabbit tongue similarly to other examined animal species such as the rat (Farbman, 1970), dog (Singh et al., 1980) and cattle (Steflik et al., 1983) there were two different kinds of keratinization of the epithelium of filiform papillae. The interpapillary epithelium was nonkeratinized stratified squamous epithelium. No keratohialine granules were found in this epithelium. Similar findings were also observed in musk shrew (Iwasaki and Miyata, 1985). For comparison, the interpapillary epithelium of rat (Farbman, 1970) contains keratohyaline granules.

In conclusion, our study has shown, that the filiform papillae of the rabbit exhibit a distinctive morphology. Different morphological types of filiform papillae, which were observed and their arrangement on the tongue, can help to understand how the tongue is adapted to its function in this species. 
Kulawik, M., Godynicki, Sz., Frąckowiak, H. (2015). Light and scanning electron microscopic study of the filiform papillae of the tongue in adult rabbit (Oryctolagus cuniculus f. domestica, Linnaeus 1758). Nauka Przyr. Technol., 9, 1, \#12. DOI: 10.17306/J.NPT.2015.1.12

\section{Conclusions}

1. The single filiform papillae were cone-shaped, similarly to their connective tissue cores.

2. The complex filiform papillae were palm-shaped and cone-shaped with three to seven processes. Their connective tissue cores had also processes.

3 . The anterior epithelial cell column of filiform papillae showed signs of parakeratinization or soft keratinization whereas the posterior epithelial cell column - hard keratinization.

\section{References}

Barone, R., Pavaux, P. C., Blin, C., Cuq, P. (1973). Atlas d'anatomie du lapin. Atlas of rabbit anatomy. Paris: Masson \& Cie.

Burity, C. H. De F., Silva, M. R., Souza, A. M., Lancetta, C. F. F., Medeiros, M. F., Pissinatti, A. (2009). Scanning electron microscopic study of the tongue in golden-headed lion tamarins, Leontopithecus chrysomelas (Callithrichidae: Primates). Zoologia (Curitiba), 26, 323-327.

Choudhury, A. R., Khan, M., Baba, M. A. (2013). A histomorphological study on the tongue of musk deer (Moschus moschiferus). Indian J. Vet. Anat., 25, 105-106.

Ciuccio, M., Estecondo, S., Casanave, E. B. (2008). Scanning electron microscopy study of the dorsal surface of the tongue in Zaedyus pichiy (Mammalia, Xanarthra, Dasypodidae). Int. J. Morphol., 26, 13-18.

El-Bakry, A. M. (2010). Study by transmission and scanning electron microscopy of the morphogenesis of three types of lingual papillae in the albino rat (Rattus rattus). Acta Zool. (Stockh.), 91, 267-278.

Emura, S., Okumura, T. Chen, H. (2008). Morphology of the lingual papillae and their connective tissue cores in the Cape hyrax. Okajimas Folia Anat. Jpn., 85, 1, 29-34.

Emura, S., Okumura, T., Chen, H., Shoumura, S. (2006). Morphology of the lingual papillae in the raccoon dog and fox. Okajimas Folia Anat. Jpn., 83, 3, 73-76.

Emura, S., Tamada, A., Hayakawa, D., Chen, H., Shoumura, S. (2001). SEM study on the dorsal lingual surface of the nutria, Myocastor coypus. Kaibogaku Zasshi, 76, 233-238.

Erdunchaolu, E., Takehana, K., Yamamoto, E., Kobayashi, A., Cao, G., Baiyin, C. A. O., Ueda, H., Tangkawattana, P. (2001). Characteristics of dorsal lingual papillae of the Bactrian camel (Camelus bactrianus). Anat. Histol. Embryol., 30, 147-151.

Estecondo, S., Codón, S. M., Casanave, E. B. (2001). Scanning electron microscopy study of the dorsal surface of the tongue in Chaetophractus vellerosus (Mammalia, Dasypodidae). Rev. Chil. Anat., 19, 3.

Farbman, A. I. (1970). The dual pattern of keratinization in filiform papillae on rat tongue. J. Anat., 106, 233-242.

Fujimoto, S., Yamamoto, K., Yoshizuka, M., Yokoyama, M. (1993). Pre- and postnatal development of rabbit foliate papillae with special reference to foliate gutter formation and taste bud and serous gland differentiation. Microsc. Res. Tech., 26, 120-132.

Iwasaki, S. (2002). Evolution of the structure and function of the vertebrate tongue. J. Anat., 201, $1-13$.

Iwasaki, S., Miyata, K. (1985). Light and transmission electron microscopic studies on the lingual dorsal epithelium of the musk shrew, Suncus murinus. Okajimas Folia Anat. Jpn., 62, 67-88. 
Kulawik, M., Godynicki, Sz., Frąckowiak, H. (2015). Light and scanning electron microscopic study of the filiform papillae of the tongue in adult rabbit (Oryctolagus cuniculus f. domestica, Linnaeus 1758). Nauka Przyr. Technol., 9, 1, \#12. DOI: 10.17306/J.NPT.2015.1.12

Iwasaki, S., Miyata, K., Kobayashi, K. (1988). Scanning electron microscopic studies of the dorsal lingual surface of the squirrel monkey. Acta Anat., 132, 225-229.

Iwasaki, S., Yoshizawa, H., Suzuki, K. (1992). Fine structure of the dorsal lingual epithelium of the Japanese monkey Macaca fuscata fuscata. Acta Anat., 144, 267-277.

Kilinc, M., Erdogan, S., Ketani, S., Ketani, M. A. (2010). Morphological study by scanning electron microscopy of the lingual papillae in the middle east blind mole rat (Spalax ehrenbergi, Nehring, 1898). Anat. Histol. Embryol., 39, 509-515.

Kobayashi, K. (1992). Stereo architecture of the interface of the epithelial cell layer and connective tissue core of the foliate papilla in the rabbit tongue. Acta Anat., 143, 109-117.

Kobayashi, K., Wanichanon, C. (1992). Stereo architecture of the connective tissue cores of the lingual papillae in the treeshrew (Tupaia glis). Anat. Embryol., 186, 511-518.

Kulawik, M., Godynicki, Sz. (2006). Foliate papillae on the tongue in the domestic rabbit (Oryctolagus cuniculus f. domestica). Electr. J. Pol. Agric. Univ. Ser. Vet. Med., 9, 3, \#19.

Kulawik, M., Godynicki, Sz. (2007a). Fungiform papillae of the tongue in the rabbit (Oryctolagus cuniculus). Pol. J. Vet. Sci., 10, 25-27.

Kulawik, M., Godynicki, Sz. (2007b). Vallate papillae in the domestic rabbit (Oryctolagus cuniculus f. domestica). Pol. J. Vet. Sci., 10, 47-50.

Kullaa-Mikkonen, A., Hynynen, M., Hyvönen, P. (1987). Filiform papillae of human, rat and swine tongue. Acta Anat., 130, 280-284.

Kumar, S., Bate, L. (2004). Scanning electron microscopy of the tongue papillae in the pig (Sus scrofa). Microsc. Res. Tech., 63, 253-258.

Kurtul, I., Atalgin, S. H. (2008). Scanning electron microscopic study on the structure of the lingual papillae of the Saanen goat. Small Rumin. Res., 80, 52-56.

Mackenzie, I. C. (1984). Epithelial-connective tissue relationships and the development and maintenance of structure. In: J. Meyer, C. A. Squier, S. J. Gerson (eds.), The structure and function of oral mucosa (pp. 119-139). Oxford: Pergamon.

Mohammed, A. H. S., Haider, S. K., Salman, R. A. (2014). Morphological study of the lingual papillae in Mellivora capensis tongue. J. US-China Med. Sci., 11, 42-46.

Ojima, K., Takahashi, T., Matsumoto, S., Takeda, M., Saiki, C. H., Mitsuhashi, F. (1997). Angioarchitectural structure of the fungiform papillae on rabbit tongue anterodorsal surface. Ann. Anat., 179, 329-333.

Okada, S., Schraufnagel, D. E. (2005). Scanning electron microscopic structure of the lingual papillae of the common opossum (Didelphis marsupialis). Microsc. Microanal., 11, 319-332.

Pastor, J. F., Barbosa, M., De Paz, F. J. (2008). Morphological study of the lingual papillae of the giant panda (Ailuropoda melanoleuca) by scanning electron microscopy. J. Anat., 212, 99-105.

Sanders, E. J. (1988). The roles of epithelial-mesenchymal cell interactions in developmental processes. Biochem. Cell Biol., 66, 530-540.

Silva, M. C. P., Watanabe, I., Kronka, M. C. (2002). Three-dimensional architecture of the connective tissue core and surface structures of the lingua papillae in the rabbit. Histol. Histopathol., 17, 455-461.

Singh, B. B., Baker, R., Boshell, J., McKinney, R. V. (1980). Observations on the eosinophilic granules in the dorsal papillae of the dog tongue. J. Oral Pathol., 9, 99-105.

Steflik, D. E., Singh, B. B., McKinney, R. V., Boshell, J. (1983). Correlated TEM, SEM, and histological observations of filiform papillae of the cow tongue. Acta Anat., 117, 21-30.

Yoshimura, K., Shindo, J., Kageyama, I. (2008). Light and scanning electron microscopic study on the tongue and lingual papillae of the Japanese badgers, Meles meles anakuma. Okajimas Folia Anat. Jpn., 85, 4, 119-127. 
Kulawik, M., Godynicki, Sz., Frąckowiak, H. (2015). Light and scanning electron microscopic study of the filiform papillae of the tongue in adult rabbit (Oryctolagus cuniculus f. domestica, Linnaeus 1758). Nauka Przyr. Technol., 9, 1, \#12. DOI: 10.17306/J.NPT.2015.1.12

Zheng, J., Kobayashi, K. (2006). Comparative morphological study on the lingual papillae and their connective tissue cores (CTC) in reeves' muntjac deer (Muntiacus reevesi). Ann. Anat., $188,555-564$.

\section{BADANIA BRODAWEK NITKOWATYCH JĘZYKA DOROSŁEGO KRÓLIKA (ORYCTOLAGUS CUNICULUS F. DOMESTICA, LINNAEUS 1758) W MIKROSKOPIE ŚWIETLNYM I ELEKTRONOWYM SKANINGOWYM}

Streszczenie. Badania prowadzono na 10 językach dorosłych królików (Oryctolagus cuniculus f. domestica) obu płci (pięć samic i pięć samców). Brodawki nitkowate języka badano, używając mikroskopu świetlnego i mikroskopu elektronowego skaningowego. Brodawki nitkowate były rozmieszczone na powierzchni grzbietowej wierzchołka i trzonu języka oraz na jego brzegach. Badania wykazały, że na języku królika znajdowały się pojedyncze i złożone brodawki nitkowate. Pojedyncze brodawki nitkowate były kształtu stożkowatego, podobnie jak ich zręby łącznotkankowe. Brodawki nitkowate złożone były kształtu dłoniastego i stożkowatego z trzema-siedmioma wyrostkami. Jednakże liczba wyrostków w kierunku gardła zmniejszała się. Zręby łącznotkankowe tych brodawek miały także wyrostki. Brodawki nitkowate składały się z przedniej i tylnej kolumny komórek nabłonkowych. Przednia kolumna nabłonkowa wykazywała oznaki pararogowacenia lub miękkiego rogowacenia, natomiast tylna kolumna komórek nabłonkowych - twarde rogowacenie. Pomiędzy brodawkami nitkowatymi znajdował się nabłonek międzybrodawkowy, który nie wykazywał oznak rogowacenia.

Słowa kluczowe: królik, język, brodawki nitkowate

Corresponding address - Adres do korespondencji:

Mirostawa Kulawik, Instytut Zoologii, Uniwersytet Przyrodniczy w Poznaniu, ul. Wojska Polskiego 71 C, 60-625 Poznań, Poland, e-mail: kulawik@up.poznan.pl

Accepted for publication - Zaakceptowano do opublikowania: 17.10.2014

For citation - Do cytowania:

Kulawik, M., Godynicki, Sz., Frackowiak, H. (2015). Light and scanning electron microscopic study of the filiform papillae of the tongue in adult rabbit (Oryctolagus cuniculus $f$. domestica, Linnaeus 1758). Nauka Przyr. Technol., 9, 1, \#12. DOI: 10.17306/J.NPT.2015.1.12 